\title{
ENVIRONMENTAL BASELINE GEOCHEMISTRY OF SEDIMENTS AND PERCOLATING WATERS IN THE MODRIĆ CAVE, CROATIA
}

OCENA OKOLJSKE GEOKEMIJE V JAMI MODRIĆA NA HRVAŠKEM, PREDEN BO ODPRTA ZA TURIZEM

SLOBODAN MIKO $^{1} \&$ MLADEN KUHTA $^{1} \&$ SANJA KAPELJ ${ }^{1}$

${ }^{1}$ Institute of Geology, Sachsova 2, HR-10000 ZAGREB, CROATIA

Prejeto / received: 14. 3. 2002 


\section{Slobodan Miko \& Mladen Kuhta \& Sanja Kapelj: Ocena okoljske geokemije v jami Modrića na Hrvaškem, preden bo odprta za turizem}

Izdelana je bila predhodna podrobna študija jame Modrića, še preden bi jo uredili za turistični obisk. Meljasta ilovica z guanom vsebuje mnogo kremena, ilita in taranakita ter manjše količine vivianita in visoke koncentracije bakra (2869 mg/kg), cinka (951 mg/kg) in kadmija (28 mg/kg). Sedimenti, pomešani z guanom, so obogateni z rahlim REE in s povišanimi koncentracijami U, Th in Hg. Sedimenti z delci kosti vsebujejo kremen, ilit, kalcit in hidroxylapatit, a manj carnalita in nizke vrednosti težkih mineralov. Vsi analizirani sedimenti kažejo različno stopnjo kontaminacije $\mathrm{Cu}$ in $\mathrm{Zn}$ zaradi razsutega guana. Večina $\mathrm{Zn}$ in $\mathrm{Cu} v$ jamskih sedimentih kot tudi hidroxylapatitna skorja so v zvezi z železovim in manganovim hidroksidom ter organskimi delci. Organski delci v vzorcih sedimentov so pomembni, ker kažejo neposredni vpliv guana in hidroxylapatitnih skorij, medtem ko je v vzorcih sedimentov z drobci kosti najpomembnejši hidroksid. V dveh primerih smo opazovali vpliv guana na prenikajočo vodo v levem rovu, kjer je večja koncentracija ortofosfatov glede na hidroxylapatit. Ključne besede: speleologija, jamski sediment, jamski mineral, guano, Modrić jama, Severna Dalmacija, Hrvaška.

\section{Abstract}

UDC: 550.4:551.442(497.5)556.31(497.5)

\section{Slobodan Miko \& Mladen Kuhta \& Sanja Kapelj: Environmental baseline geochemistry of sediments and percolating waters in the Modrić Cave, Croatia}

A comprehensive study of Modrić cave was undertaken to evaluate the baseline conditions before its utilization for tourism. Silty loams with guano contain abundant quartz, illite and taranakite and minor vivianite and high concentrations of $\mathrm{Cu}(2869 \mathrm{mg} / \mathrm{kg}), \mathrm{Zn}(951 \mathrm{mg} / \mathrm{kg})$ and $\mathrm{Cd}(28 \mathrm{mg} / \mathrm{kg})$. Also sediments mixed with guano are enriched with light REE as well as elevated concentrations of $\mathrm{U}, \mathrm{Th}, \mathrm{Rb}$ and $\mathrm{Hg}$. Sediments with bone fragments contain abundant quartz, illite, calcite and hydroxylapatite and minor carndallite and lower contents of heavy metals. All sediments analysed showed various degrees of contamination by $\mathrm{Cu}$ and $\mathrm{Zn}$ from dispersed guano. Most of the $\mathrm{Zn}$ and $\mathrm{Cu}$ in cave sediments and the hydroxyl-apatite crusts are mainly controlled by the iron and manganese hydroxide and the organic fractions, the organic fraction plays an important role in sediment samples with direct influence of guano and in hydroxylapatite crusts while in samples with bone fragments the hydroxide control is dominant. Guano influence on the percolating waters was observed in two cases in the left channel where due to the higher content of orthophosphates saturation in respect to hydroxyl-apatite is present.

Key words: speleology, cave sediment, cave mineral, guano, Modrić cave, North Dalmatia, Croatia. 


\section{INTRODUCTION}

The entrance to Modrić cave located in the central part of the Croatian coastal region (Fig. 1) was used by local population as a natural shelter for centuries, but the underground network of channels and chambers was discovered in 1985. Since the cave was naturally sealed from its entrance an opening was chiselled through opened fissures in the limestone. The local authorities managed to prevent devastation of speleothems by controlling of entries made to the cave system. The favorable morphology and numerous stalagmites, pillars, flowstone, helictites, draperies (Kuhta et al., 1999) etc., as well as the paleontologic and archeological remnants (Malez, 1987) preserved in the cave sediments made it attractive as a tourist destination. Therefore a comprehensive study, which included cave mapping, analysis of waters, and cave sediments, as well as age determinations (Kuhta et al., 1999) was undertaken to evaluate the baseline conditions within the cave before its utilization. The vicinity of a major highway and recent war activities (1991/1992), implied possible negative impacts on this vulnerable environment. The frequent occurrence of a

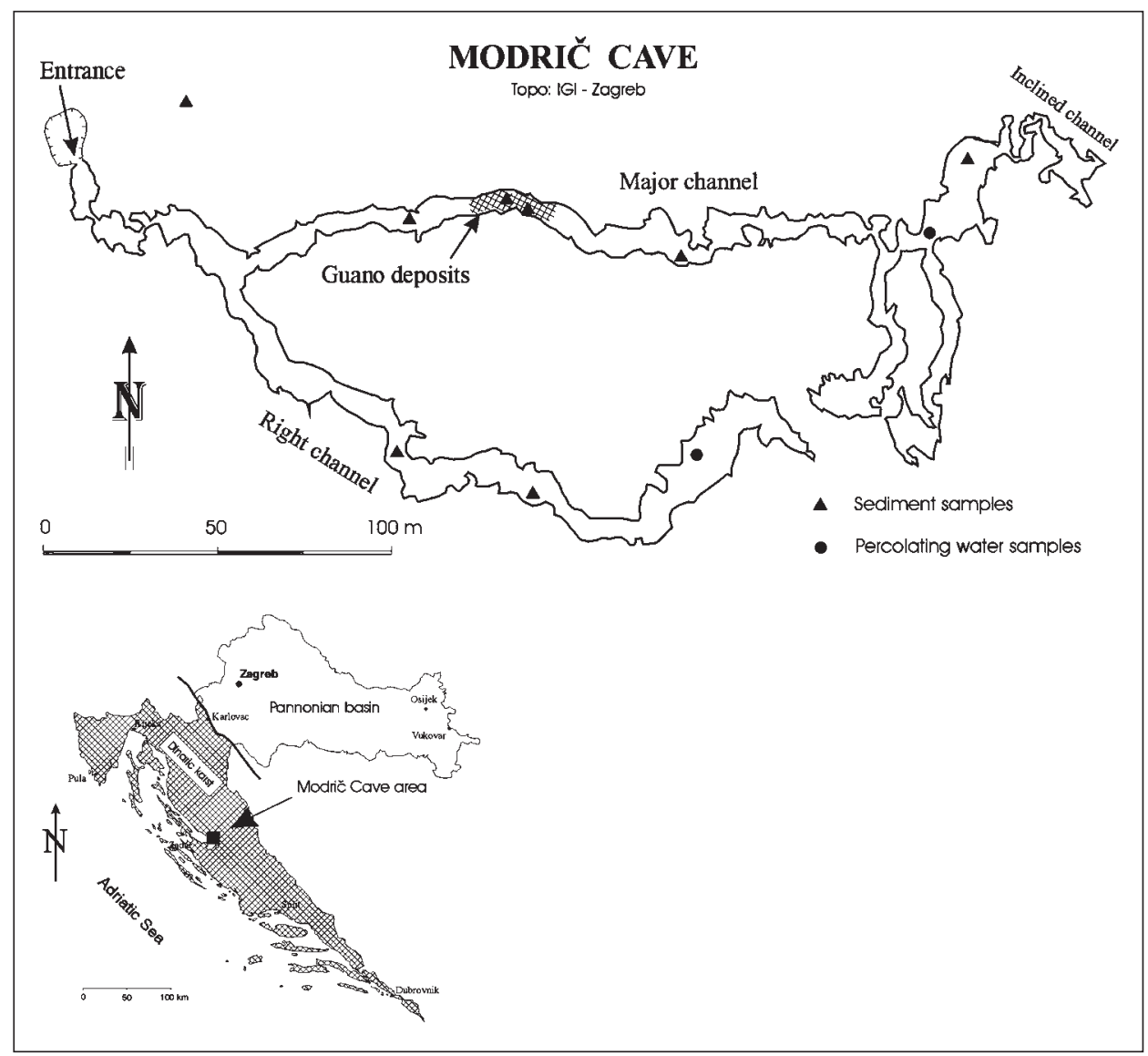

Fig. 1: Geographical position of the Modric cave system and location of sampling sites. 
thin dark crust on the floors in most depressions and on sediments was especially interesting in this sense. This was determined to be finely dispersed guano. Guano (bat guano, bird guano, penguin guano), similar to phosphates in general, is a well-known source of heavy metals. Heavy metal movement with water in sediments and soils requires that the metals be in soluble phase or associated with mobile particles and as such can have impacts on the quality of ground water. The objective of this study was the investigation of heavy metal concentrations and the movement of elements derived from bat guano in a cave environment.

\section{GEOLOGY, HYDROGEOLOGY AND CAVE MORPHOLOGY}

Modrić cave formed within the Cenomanian-Turonian well bedded limestones. The limestones consist of poorly sorted bioclasts with a dense sparite matrix. Within the beds the occurrence of the lamellibranchiata Chondrondonta joannae is quite frequent. The layers often contain lenses of platy limestones containing foraminifera and rarely macrofossils. The youngest quaternary beds that cover the bedrock are thin chromic cambisols, which accumulated in openings of karstified fissures and local depressions.

The wider region of the cave is located within the contact zone of the Adriatic carbonate platform structural complex and the Dinaric carbonate platform. The surface manifestation of the contact zone is a $2.5 \mathrm{~km}$ wide fault zone termed the Velebit fault (Herak, 1986). This regional tectonic structure consists of a series of parallel faults with a general strike NW-SE; two of these faults are located to the north and to the south of the cave. The limestone beds have a general strike NW-SE with dip angles ranging from 20 to $40^{\circ}$ and inclination towards the NW. The faults and numerous networks of tectonic fissures formed during several tectonic events that shaped the morphology of the landscape had a key role in the formation of subsurface karst phenomena including Modrić cave. The cave is located within a series of well permeable highly karstified carbonate rocks. The surrounding karst is characterized by the absence of surface flows and a fast direct infiltration of precipitation waters and a development of complex underground geomorphologic features. The infiltrated precipitation waters are drained through the complex systems of karstified fissures directly towards the sea. There are no concentrated discharges of fresh water along the coast so outflow of the water probably occurs in a depressive manner. The cave is located above groundwater level and outside the present zone of active circulation. The dimensions of the underground chambers indicate an important hydrogeological role of this region in the geological past. Modrić cave formed as a consequence of groundwater activity, during which groundwater flowed from the regional Velebit Mt. karst aquifer towards the terrain located at lower altitudes, i.e. towards the morphological depression of the present sea channel the Velebit channel. Active parts of this system exist nearby in the form of submarine springs Modrić (-30 m) and Zečica $(-45 \mathrm{~m})$ and the coastal spring Velebit.

The entrance to the cave $(1.8 \mathrm{~m} \times 1.3 \mathrm{~m})$ is located at altitude of $30 \mathrm{~m}$ above sea level some $70 \mathrm{~m}$ away from a major coastal highway Rijeka-Zadar. The basic morphological features of the cave are slightly inclined to horizontal chambers and channels, which have been explored to a total length of $829 \mathrm{~m}$. From the entrance the cave extends generally towards the east. The elevation difference from the lowest point in the middle of the Major channel (Glavni kanal) and the highest point in the inclined channel (Kosi kanal) is $29 \mathrm{~m}$. In most parts of the cave the width of 
the passages ranges from 2 to $8 \mathrm{~m}$ and in parts extends up to $14 \mathrm{~m}$. As a consequence of stalagmite formation and flowstone deposition the channels were almost closed so it was necessary to widen them. The sediment deposits are found in larger chambers and various depressions within the cave. The sediments are mainly silt loams and clay silt loams of reddish-brown to brown color (5YR to 7.5YR), with calcareous debris and numerous bone fragments of Holocene fauna (Ursus Spelaeus), human bone remains and remnants of Eneolithic pottery (Malez, 1987). The structure of the sediments is quite chaotic, lacking visible stratification, with variable thickness from several centimeters to probably over $1.5 \mathrm{~m}$. Dark brown and white bat guano deposits occur in several places covering the sediments up to $1 \mathrm{~m}$ over a surface of several square meters (central part of the main channel, Fig. 1). A thin gray layer that covers the damp sediments and the floor of the cave was determined to be of finely dispersed guano. The bats are not frequent residents of the cave today, since the entrance was first opened in 1985.

\section{METHODOLOGY}

Typical sediment samples (sediments with bone fragments from various depths from the sediment profile, sediments mixed with guano, dark mud coatings over sediments and dark crusts with dissolution surfaces on flowstone) and soil samples from the surface above the cave were selected for geochemical and mineralogical analyses. The objective of the geochemical study was to determine the baseline concentrations of elements (total and aqua regia extraction), their mobility and mineral phases (sequential extraction) and to evaluate possible anthropogenic influences. A highly potential pollution source considered was the heavy traffic from the nearby highway. Detailed analysis of 20 cave sediment samples was performed.

Major and trace element values including REE were obtained after $\mathrm{LiBO}_{3}$ fusion by ICP-AES and ICP-MS, also additional analysis were performed after aqua regia $\left(\mathrm{HNO}_{3}: \mathrm{HCl}, 1: 3\right)$ extraction to verify the high heavy metal contents in the sediments. The residence sites of metals in the sediments were identified by sequential extraction performed with the aid of a modified combination of procedures proposed by Tessier et al., (1979) and Hall et al., (1996). Sequential extraction of the sediment samples was performed to give the following five fractions: adsorbed (AD), bound to carbonate (CC), bound to iron and manganese oxides (FEMN), bound to organic matter and sulphides (OR) and residual (RES). A detailed review of the procedure used in this study is shown in Table 1. It must be recognised that results obtained are "operationally defined", i.e.

Table 1: Sequential extraction scheme.

\begin{tabular}{|c|c|c|c|c|}
\hline STEP & FRACTION & SOLUTION & VOLUME & CONDITIONS \\
\hline $1(\mathrm{AD})$ & exchangeable & $1 \mathrm{M} \mathrm{NH} 4 \mathrm{Ac}(\mathrm{pH} 7)$ & $12 \mathrm{ml}$ & shake, $1 \mathrm{~h}$ \\
\hline $2(\mathrm{CC})$ & carbonates & $0.1 \mathrm{M} \mathrm{NaOAc}(\mathrm{pH} 5)$ & $20 \mathrm{ml}$ & shake, $6 \mathrm{~h}$ \\
\hline $3(\mathrm{FEMN})$ & Fe-Mn oxides & $\begin{array}{c}1 \mathrm{M} \mathrm{NH} 2 \mathrm{OHxHCl} \text { in } \\
25 \% \mathrm{HAc}\end{array}$ & $15 \mathrm{ml}$ & $\begin{array}{c}\text { boiling water bath }\left(90^{\circ}\right), 3 \mathrm{~h}, \\
\text { occasionally agitation }\end{array}$ \\
\hline 4(ORG) & organic & $30 \% \mathrm{H} 2 \mathrm{O} 2+\mathrm{HNO} 3$ & $10 \mathrm{ml}+3 \mathrm{ml}$ & $\begin{array}{c}\text { boiling water bath }\left(86^{\circ}\right), 2 \mathrm{~h}, \\
\text { occasionally agitation }\end{array}$ \\
\hline $5(\mathrm{RES})$ & residual & aqua regia $+\mathrm{HF}$ & $5 \mathrm{ml}+4 \mathrm{ml}$ & microwave digestion, $2 \mathrm{~h}$ \\
\hline
\end{tabular}


selectivity is not $100 \%$ and is dependent upon such factors as the type of chemicals employed, sample to volume ratio, grain size etc. (Hall et al. 1996). The amount of exchangeable fractions of elements was determined after extraction with $1 \mathrm{M} \mathrm{KCl}$. All solutions were analysed for $\mathrm{Zn}, \mathrm{Cu}$, $\mathrm{Fe}, \mathrm{Mn}, \mathrm{Al}, \mathrm{P}$ and Ni by a Jobin Yvon 50P simultaneous inductively coupled plasma-atomic emission spectrophotometer (ICP-AES) and $\mathrm{Pb}$ and $\mathrm{Cd}$ by a Pye Unicam SP9 flame atomic absorption spectrophotometer (AAS) using an air-acetylene flame. Filtered $(-45 \mu \mathrm{m})$ samples of percolating drop water were analysed by ICP-MS. The water sampling was performed during three different periods (spring, summer and winter). Mineral composition of selected samples was analysed with a Philips diffractometer ( $\mathrm{CuK} \alpha$ radiation) equipped with a graphite monochromator and proportional counter.

\section{RESULTS AND DISCUSSION}

\section{Cave sediment mineralogy}

The cave sediments were found to contain a variety of typical phosphate minerals (Table 2.) found in cave environments influenced by reactions between soil clay minerals and carbonate

Table 2: Mineralogical composition of selected samples.

\begin{tabular}{|c|c|c|c|c|c|c|c|c|c|}
\hline & \multirow{2}{*}{\multicolumn{2}{|c|}{$\begin{array}{l}\text { Sediments with } \\
\text { guano } \\
\text { fraction }\end{array}$}} & \multirow{3}{*}{$\begin{array}{l}\text { Guano } \\
\text { fraction } \\
<63 \mu \mathrm{m} \\
\end{array}$} & \multirow{3}{*}{\multicolumn{2}{|c|}{$\begin{array}{c}\text { Sediments with } \\
\text { bones } \\
\text { fraction } \\
<63 \mu \mathrm{m}<2 \mu \mathrm{m}\end{array}$}} & \multirow{2}{*}{\multicolumn{2}{|c|}{$\begin{array}{l}\text { Topsoil } \\
\text { fraction }\end{array}$}} & \multicolumn{2}{|c|}{$\begin{array}{l}\text { Hydroxyl-apatite } \\
\text { encrustations }\end{array}$} \\
\hline & & & & & & & & \multirow{2}{*}{$\begin{array}{l}\text { surface } \\
0-0,5 \mathrm{~mm}\end{array}$} & \multirow{2}{*}{$\begin{array}{r}\text { below surf. } \\
0,5-5 \mathrm{~mm} \\
\end{array}$} \\
\hline & $<63 \mu \mathrm{m}$ & $<2 \mu \mathrm{m}$ & & & & $<63 \mu \mathrm{m}$ & $<2 \mu \mathrm{m}$ & & \\
\hline Apatite & & & & + & + & & & & \\
\hline Hydroxyl- & & & & & & & & +++ & +++ \\
\hline \multicolumn{10}{|l|}{ apatite } \\
\hline Taranakite & +++ & +++ & +++ & & & & & & \\
\hline Crandallite & & & & + & + & & & & \\
\hline Vivianite & + & + & + & & & & & & \\
\hline Quartz & +++ & +++ & ++ & +++ & +++ & +++ & + & + & \\
\hline Calcite & + & & + & ++ & ++ & + & + & + & + \\
\hline Kaolinite & & & + & & ++ & +++ & +++ & & \\
\hline Illite & +++ & & +++ & +++ & +++ & & & & \\
\hline Plagioklase & & & & + & + & & & & \\
\hline Potassium & & & & & + & + & & & \\
\hline \multicolumn{10}{|l|}{ fedspar } \\
\hline Gibbsite & & & & & & + & + & & \\
\hline Getite & & & & & & + & + & & \\
\hline Amorphous & & & & & +++ & & & & \\
\hline \multicolumn{10}{|l|}{ matter } \\
\hline Anatase & & & $?$ & & $?$ & & & & \\
\hline
\end{tabular}

Explanation: +++ major constituent ; ++ minor constituents; + traces; ? possibly present;

Explanation: +++ major constituent ; ++ minor constituents; + traces; ? possibly present; 
bedrock with bat guano (Murray \& Deitrich, 1956; Hill, 1976, Cancain et al., 1989; Cancain et al., 1992; Cancain \& Princiviale, 1997)

The $\mathrm{X}$-ray diffraction analysis showed that the acid $\left(\mathrm{pH}_{\mathrm{H} 2 \mathrm{O}}\right.$ from 3 to 6$)$ sediments with variable contents of guano contain abundant quartz, illite and taranakite $\left(\mathrm{H}_{6} \mathrm{~K}_{3} \mathrm{Al}_{5}\left(\mathrm{PO}_{4}\right)_{8} \times 18 \mathrm{H}_{2} \mathrm{O}\right)$, and minor vivianite $\left(\mathrm{Fe}_{5}\left(\mathrm{PO}_{4}\right)_{2} \times 8 \mathrm{H}_{2} \mathrm{O}\right)$, the almost "pure" guano sample had a similar composition but with a large amount of amorphous/organic matter. The potassium phosphate taranakite forms as a reaction product between potassium bearing clay minerals and guano. The presence of vivianite in these samples indicates that a reduction of $\mathrm{Fe}^{3+}$ to $\mathrm{Fe}^{2+}$ occurred in the sediments. This implies either a reducing freshwater environment, or to bacterial activity in the presence of organics, which are also known to contribute to the reduction of iron compounds in a phosphatebearing environment (Suess, 1978, Fischer, 1988). Sediments (containing bone fragments) with no visible guano presence $(\mathrm{pH}>6)$ contain abundant quartz, illite, calcite and apatite with scarce carndallite $\left.\left(\mathrm{CaAl}_{3}\left(\mathrm{PO}_{4}\right)_{2}(\mathrm{OH})_{5}\right) \times \mathrm{H}_{2} \mathrm{O}\right)$. The dark crusts with dissolution surfaces on flowstone consist of fibrous hydroxyl-apatite (2-3 mm thick) and pinkish white earthy masses $(5-10 \mathrm{~mm}$ wide) of hydroxyl-apatite $\left(\mathrm{Ca}_{5}\left(\mathrm{PO}_{4}\right)_{3} \mathrm{OH}\right)$ and sporadic calcite and clay minerals. The analysed almost pure hydroxyl-apatite was found to contain high concentrations of $\mathrm{Zn}, \mathrm{Cu}$ and $\mathrm{Cd}$. All of these heavy metals form phosphates in the presence of calcium ions in soil environments occur in form of solid solutions of heavy metals and alkali metal phosphates (Ayati et al., 2000).

\section{Cave sediment geochemistry}

\section{Concentrations of heavy metals}

The total contents of elements obtained after $\mathrm{LiBO}_{3}$ fusion presented in Table 3. show elevated, $\mathrm{P}_{2} \mathrm{O}_{5}, \mathrm{Cu}, \mathrm{Zn}, \mathrm{Th}, \mathrm{U}, \mathrm{Sb}$ and $\mathrm{Cd}$ concentrations in cave sediments in respect to local topsoil. Other heavy metals in comparison with regional soil data are well within the geochemical background (Miko et al., 2000). The concentration of $\mathrm{Pb}$ in topsoil above the cave $(46 \mathrm{mg} / \mathrm{kg}$ ) is similar to the regional mean $(49 \mathrm{mg} / \mathrm{kg}$ - data from Miko et al., 2000), and the low concentrations of this metal (approx. $25 \mathrm{mg} / \mathrm{kg}$ ) in the cave sediments (with and without guano) indicate that the vicinity of the major road had no direct influence on the geochemistry of the cave sediments. The high concentrations of $\mathrm{Zn}, \mathrm{Cd}$, and $\mathrm{Cu}$ in cave sediments are a rare occurrence in Croatian caves, since previous studies as presented by Vrbek et al., (1998) for several caves in the Croatian karst region show values much lower than local/regional soils (probably due to the calcium carbonate dilution effect as a consequence of calcite presence in the sediments). Aqua regia extraction of 12 sediment samples from various depths and locations within the cave gave $\mathrm{Cu}$ concentrations ranging from 34 to $450 \mathrm{mg} / \mathrm{kg}$, Zn from 181 to $1181 \mathrm{mg} / \mathrm{kg}$ and Cd from 0.3 to $4.3 \mathrm{mg} / \mathrm{kg}$. Almost "pure" bat guano contained high concentrations of $\mathrm{Cu}(2869 \mathrm{mg} / \mathrm{kg}), \mathrm{Zn}(951 \mathrm{mg} / \mathrm{kg})$ and $\mathrm{Cd}$ $(28 \mathrm{mg} / \mathrm{kg}$ ). Very high concentrations of these elements (Zn $1181 \mathrm{mg} / \mathrm{kg} ; \mathrm{Cu} 385 \mathrm{mg} / \mathrm{kg}$; $\mathrm{Cd} 4.3 \mathrm{mg} / \mathrm{kg}$ ) were found in the dark fine mud coatings (approximately $5 \mathrm{~mm}$ thick) that cover most of the floor sediments. These coatings are finely dispersed guano deposited by water in various pools and depressions. These dark coatings cover almost all parts of the cave floor. The content of these metals is usually much lower in sediments from deeper parts of the cave sediment profiles. In comparison with the concentrations in topsoil above the cave, $\mathrm{Cu}$ and $\mathrm{Zn}$ are regularly elevated within the whole profiles. Although bat guano contains up to $2869 \mathrm{mg} / \mathrm{kg}$ of $\mathrm{Cu}$ only $0.7 \mathrm{mg} / \mathrm{kg}(0.03 \%)$ was extracted by $1 \mathrm{M} \mathrm{KCl}$ (which was used to simulates water extract- 
Table 3: Chemical composition of selected cave sediments and topsoil.

\begin{tabular}{|c|c|c|c|c|c|c|}
\hline & $\begin{array}{l}\text { Topsoil } \\
\text { above cave }\end{array}$ & $\begin{array}{l}\text { Sediment } \\
\text { with } \\
\text { bone frag. }\end{array}$ & $\begin{array}{l}\text { Sediment } \\
\text { below guano }\end{array}$ & $\begin{array}{l}\text { Sediment } \\
\text { with } \\
\text { guano }\end{array}$ & $\begin{array}{l}\text { Hydroxyl- } \\
\text { apatite } \\
\text { (pure) } \\
\text { crusts }\end{array}$ & $\begin{array}{l}\text { Hydroxyl- } \\
\text { apatite } \\
\text { (impure) } \\
\text { crusts }\end{array}$ \\
\hline Depth & $0-25 \mathrm{~cm}$ & $40-60 \mathrm{~cm}$ & $20-30 \mathrm{~cm}$ & $0-5 \mathrm{~cm}$ & $0-0.5 \mathrm{~mm}$ & $0.5-5 \mathrm{~mm}$ \\
\hline $\mathrm{pH}_{\mathrm{H} 2 \mathrm{O}}$ & 6.07 & 6.36 & 6.77 & 3.19 & n.a. & n.a. \\
\hline $\mathrm{SiO}_{2} \%$ & 40.12 & 55.26 & 44.88 & 35.45 & n.a. & n.a. \\
\hline $\mathrm{Al}_{2} \mathrm{O}_{3} \%$ & 18.14 & 14.49 & 16.68 & 13.95 & 2.79 & 12.19 \\
\hline $\mathrm{Fe}_{2} \mathrm{O}_{3} \%$ & 7.21 & 6.06 & 6.2 & 5.54 & 0.88 & 5.73 \\
\hline $\mathrm{MgO} \%$ & 1.14 & 0.69 & 1.22 & 0.93 & 0.09 & 0.63 \\
\hline $\mathrm{CaO} \%$ & 2.36 & 5.79 & 9.43 & 16 & 49.39 & 25.28 \\
\hline $\mathrm{Na}_{2} \mathrm{O} \%$ & 0.33 & 0.14 & 0.26 & 0.21 & 0.08 & 1.71 \\
\hline $\mathrm{K}_{2} \mathrm{O} \%$ & 1.28 & 1.71 & 2.03 & 1.54 & 0.13 & 1.51 \\
\hline $\mathrm{TiO}_{2} \%$ & 0.98 & 1.03 & 0.92 & 0.81 & 0.09 & 0.52 \\
\hline $\mathrm{P}_{2} \mathrm{O}_{5} \%$ & 0.31 & 5.51 & 3.36 & 5.84 & 39.46 & 9.66 \\
\hline $\mathrm{MnO} \%$ & 0.18 & 0.05 & 0.16 & 0.14 & 0.05 & 0.18 \\
\hline LOI \% & 27.8 & 9.1 & 14.7 & 19.4 & n.a. & n.a. \\
\hline Ctot $\%$ & 7.63 & 0.19 & 1.3 & 3.28 & n.a. & n.a. \\
\hline Stot $\%$ & 0.14 & 0.01 & 0.01 & 0.03 & n.a. & n.a. \\
\hline $\mathrm{Co} \mathrm{mg} / \mathrm{kg}$ & 19.9 & 8.5 & 17 & 14.5 & 1 & 12 \\
\hline $\mathrm{Rb} \mathrm{mg} / \mathrm{kg}$ & 98.6 & 90.7 & 123.2 & 95.6 & 7 & 80 \\
\hline $\mathrm{Sr} \mathrm{mg} / \mathrm{kg}$ & 70 & 270 & 74 & 75 & 41 & 148 \\
\hline $\mathrm{Th} \mathrm{mg} / \mathrm{kg}$ & 15.5 & 16.7 & 22.1 & 17.1 & 1 & 13 \\
\hline $\mathrm{U} \mathrm{mg} / \mathrm{kg}$ & 3.2 & 5.8 & 5.9 & 7.4 & 1 & 4 \\
\hline $\mathrm{V} \mathrm{mg} / \mathrm{kg}$ & 170 & 139 & 167 & 154 & 25 & 110 \\
\hline $\mathrm{Cu} \mathrm{mg/kg}$ & 32 & 63 & 62 & 165 & 130 & 541 \\
\hline $\mathrm{Zn} \mathrm{mg/kg}$ & 102 & 359 & 269 & 557 & 1929 & 1490 \\
\hline $\mathrm{Ni} \mathrm{mg} / \mathrm{kg}$ & 57 & 25 & 53 & 41 & 27 & 50 \\
\hline $\mathrm{Pb} \mathrm{mg} / \mathrm{kg}$ & 46 & 21 & 26 & 21 & $<3$ & 30 \\
\hline As $\mathrm{mg} / \mathrm{kg}$ & 28 & 16 & 22 & 20 & 4 & 17 \\
\hline $\mathrm{Cd} \mathrm{mg/kg}$ & 1.7 & 1.5 & 1.4 & 2.8 & 3.3 & 4.6 \\
\hline $\mathrm{Sb} \mathrm{mg} / \mathrm{kg}$ & 0.5 & 0.7 & 1.2 & 1.3 & 1 & 2 \\
\hline $\mathrm{Ba} \mathrm{mg} / \mathrm{kg}$ & 245 & 333 & 337 & 288 & 49 & 263 \\
\hline
\end{tabular}

able quantities of metals) while at the same time $78 \mathrm{mg} / \mathrm{kg}$ of $\mathrm{Zn}$ were extracted from a total of $951 \mathrm{mg} / \mathrm{kg}$ (i.e. $8.2 \%$ of exchangeable Zn). Due to the acidity of these sediments the mobility of $\mathrm{Al}$ was also found to be high. Therefore it is possible that the waters that percolate through the guano into deeper parts of the profile carry much more $\mathrm{Zn}$ and accumulate it there. Copper is obviously less mobile and retained in the surface layers. The dependence of exchangeable $\mathrm{Al}$ (1 M KCl extraction) and the $\mathrm{pH}$ of the sediments in presented in Fig. 2. The amount of guano mixed with the sediment greatly influences the destruction of clay minerals in the sediment, which is manifested by the release of $\mathrm{Al}$ to the water solution. Some of the analysed percolating waters also show elevated concentrations of these elements, which is an indication that a part of the water flows over guano. 


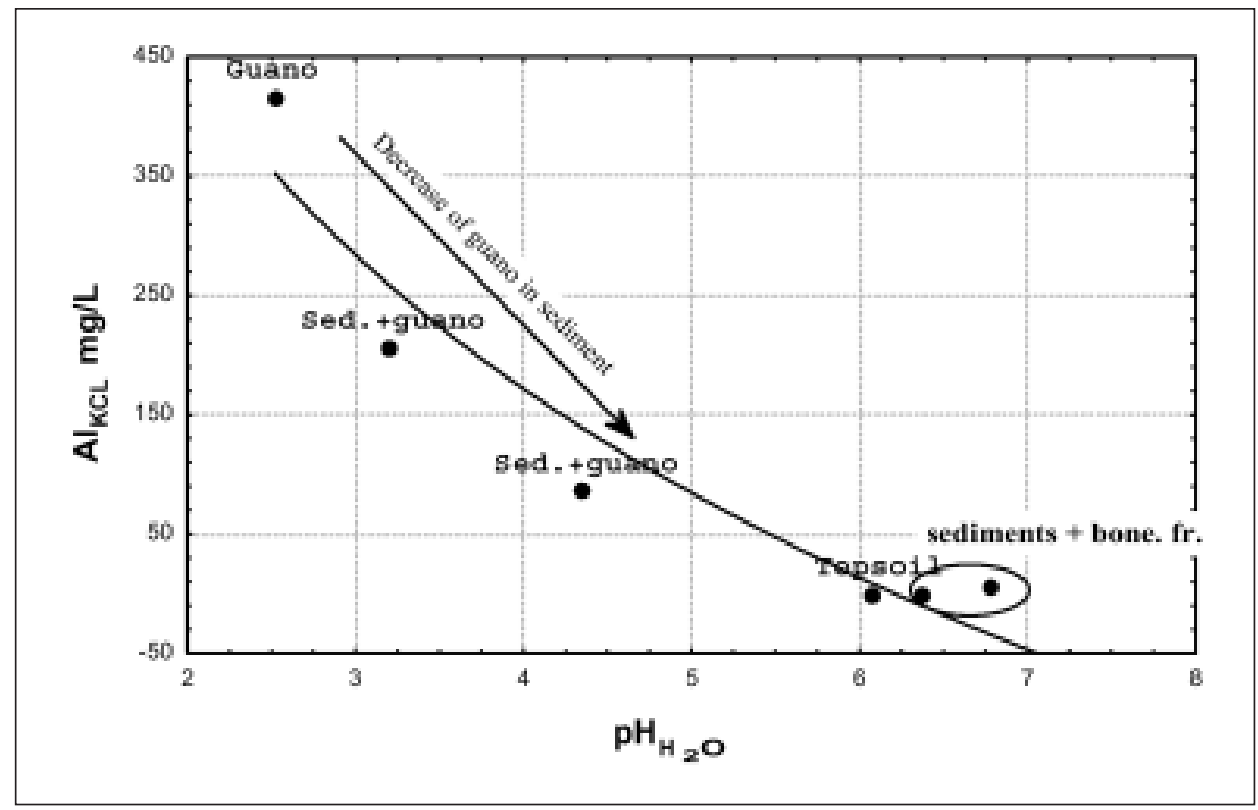

Fig. 2: The dependence of exchangeable Al (1 M KCl extraction) and the $\mathrm{pH}$ of the sediments and topsoil.

\section{Sequential extraction of heavy metals}

Sequential extraction was used to determine the metal-bearing phases in the cave sediments and for discrimination of possible lithological and environmental effects. The mobility of the metals decrease approximately in the order of the extraction sequence. The operationally defined extraction sequence follows the order of decreasing solubility of the geochemical forms of the metals; hence the exchangeable fraction may indicate which metals are most mobile. The results of chemical sequential extraction analysis show that most of the $\mathrm{Zn}$ and $\mathrm{Cu}$ in cave sediments and the hydroxyl-apatite crusts are mainly controlled by the iron and manganese hydroxide (FEMNfraction) and the organic fractions (OR) (Figs. $3 \& 4$ ), the organic fraction plays an important role in sediment samples with direct influence of guano and in hydroxyl-apatite crusts while in samples with bone fragments the hydroxide control of element distribution is dominant.

The residual (RES) fraction holds more than $45 \%$ of the total $\mathrm{Zn}$ content of the hydroxylapatite crusts indicating an incorporation of $\mathrm{Zn}$ into the crystal structure. Guano influenced sediments contain 5 to $10 \%$ of $\mathrm{Zn}$ and $\mathrm{Cu}$ in the most mobile fractions; the adsorbed (AD-less) and the carbonate (CC-more). These most liable fractions of elements in cases of heavy metal pollution studies are used predict mobility of the contaminant and are usually interpreted as an verification of anthropogenic source. In this case it can also be used for the evaluation of the quality of percolating cave waters. 


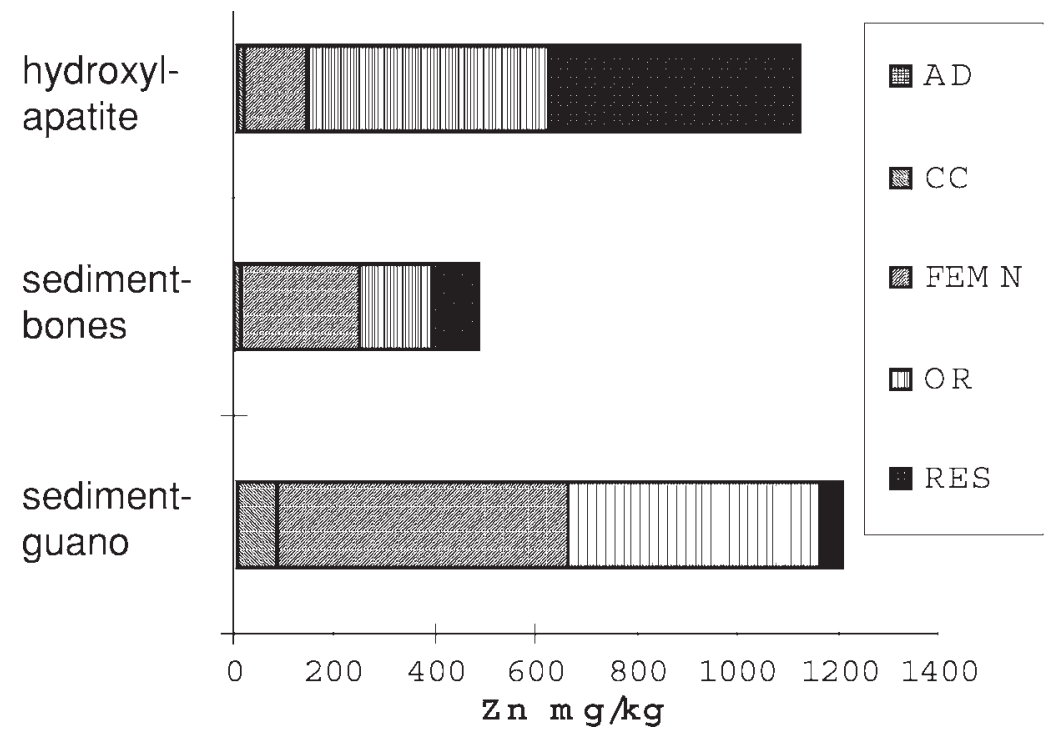

Fig. 3: Zinc concentrations in the cave sediment fractions, hydroxylapatite $=$ hydroxylapatite crusts on flowstone.

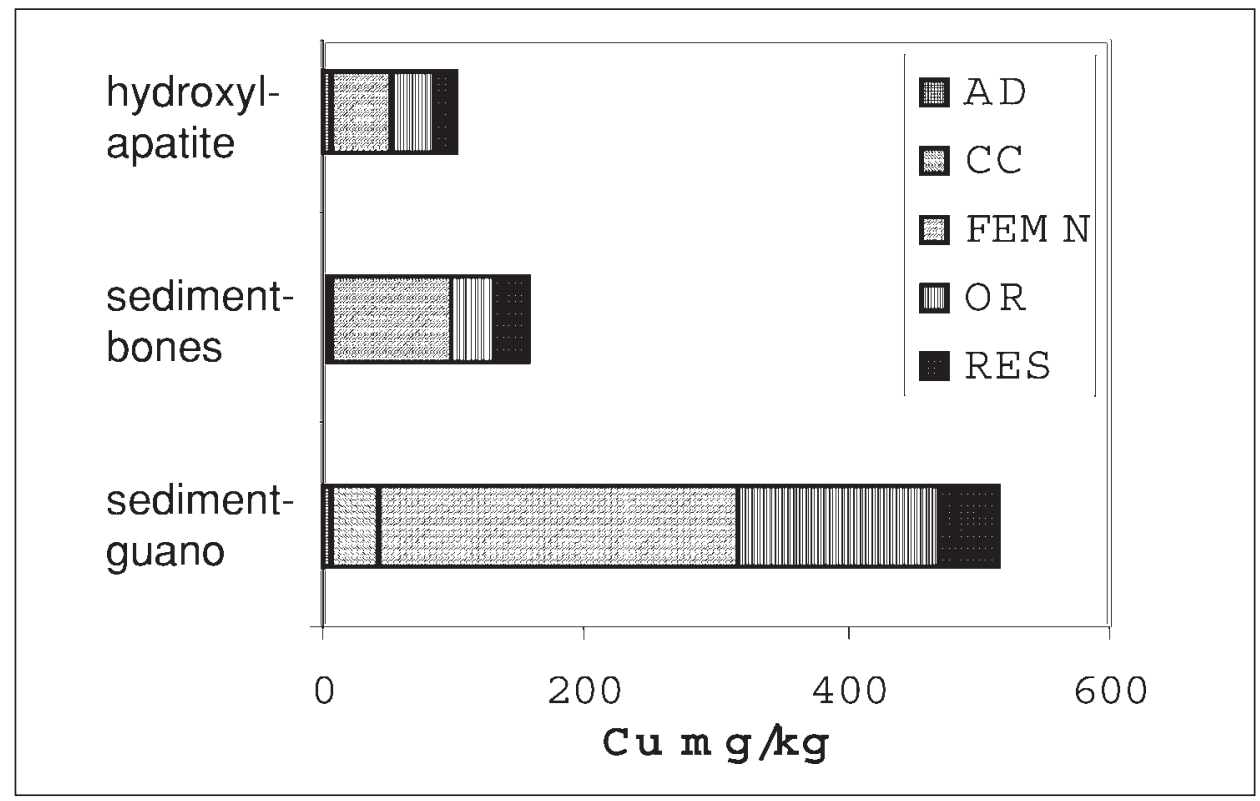

Fig. 4: Copper concentrations in the cave sediment fractions, hydroxyl-apatite = hydroxylapatite crusts on flowstone. 
Table 4: The content of rare earth (REE) elements in selected samples.

\begin{tabular}{|c|c|c|c|c|}
\hline & & $\begin{array}{c}\text { Sediment with bone } \\
\text { frag. } \\
<2 \mu \mathrm{m} \text { fraction }\end{array}$ & $\begin{array}{l}\text { Sediment with guano } \\
\quad<2 \mu \mathrm{m} \text { fraction }\end{array}$ & $\begin{array}{c}\text { Topsoil above the } \\
\text { cave } \\
<2 \mu \mathrm{m} \text { fraction }\end{array}$ \\
\hline $\mathbf{L a}$ & $\mathrm{mg} / \mathrm{kg}$ & 46,7 & 65,6 & 53,3 \\
\hline $\mathrm{Ce}$ & $\mathrm{mg} / \mathrm{kg}$ & 90,2 & 109,2 & 93,5 \\
\hline Pr & $\mathrm{mg} / \mathrm{kg}$ & 9,49 & 11,11 & 10,52 \\
\hline Nd & $\mathrm{mg} / \mathrm{kg}$ & 35,3 & 39,5 & 41,8 \\
\hline Sm & $\mathrm{mg} / \mathrm{kg}$ & 6,8 & 6,6 & 7,4 \\
\hline Eu & $\mathrm{mg} / \mathrm{kg}$ & 1,43 & 1,42 & 1,65 \\
\hline Gd & $\mathrm{mg} / \mathrm{kg}$ & 7,28 & 5,43 & 6,92 \\
\hline $\mathbf{T b}$ & $\mathrm{mg} / \mathrm{kg}$ & 1,2 & 0,75 & 0,96 \\
\hline Dy & $\mathrm{mg} / \mathrm{kg}$ & 6,4 & 4,12 & 5,81 \\
\hline Ho & $\mathrm{mg} / \mathrm{kg}$ & 1,14 & 0,91 & 1,22 \\
\hline Er & $\mathrm{mg} / \mathrm{kg}$ & 3,3 & 2,31 & 3,27 \\
\hline $\mathbf{T m}$ & $\mathrm{mg} / \mathrm{kg}$ & 0,46 & 0,42 & 0,55 \\
\hline $\mathbf{Y b}$ & $\mathrm{mg} / \mathrm{kg}$ & 3,17 & 2,27 & 3,24 \\
\hline Lu & $\mathrm{mg} / \mathrm{kg}$ & 0,54 & 0,37 & 0,48 \\
\hline$\Sigma$ REE & $\mathrm{mg} / \mathrm{kg}$ & 213,41 & 250,01 & 230,62 \\
\hline$\Sigma$ LREE & $\mathrm{mg} / \mathrm{kg}$ & 188,49 & 232,01 & 206,52 \\
\hline इHREE & $\mathrm{mg} / \mathrm{kg}$ & 23,49 & 16,58 & 22,45 \\
\hline \multicolumn{2}{|c|}{ ILREE/ $/$ HREE } & 8,02 & 13,99 & 9,20 \\
\hline
\end{tabular}

\section{Distribution of rare earth elements (REE)}

The concentration of rare earth elements in some of the typical samples (topsoil, sediments with bone fragments and sediments mixed with guano) is presented in Table 4. The chondrite normalized REE patterns calculated for the analysed samples is given in Fig. 5. The parameters such as the ratio of sums of light rare earth elements (LREE) and heavy rare earth elements (HREE) are also given in Table 4. The results of the analysed samples were compared with the European shale composite (ES). The sum of rare earth elements in ES is $204 \mathrm{mg} / \mathrm{kg}$ and the ratio of the sum of light and heavy rare earths (LLREE/LHREE) is 7.9. The distribution of rare earth elements in cave sediments with guano shows a slight enrichment of light rare earths (LREE) in comparison to European shale (ES) and depletion of heavy rare earths (HREE), while sediments and topsoil in general have similar distribution pattern to ES with only a slight enrichment of La in topsoil (Fig. 5). The REE patterns of the sediments and soil indicate a similar source of origin.

\section{Percolating water geochemistry}

Some of the percolating waters, which are of the $\mathrm{Ca}-\mathrm{HCO}_{3}$ type, collected from the ceiling were found to be enriched in the same elements as the sediments polluted by guano. The "uncontaminated" filtered $(-45 \mu \mathrm{m})$ waters contained $2 \mu \mathrm{g} / \mathrm{L}$ of $\mathrm{Zn}, 0.012 \mu \mathrm{g} / \mathrm{L}$ of $\mathrm{Cd}, 0,4 \mu \mathrm{g} / \mathrm{L}$ of $\mathrm{Cu}$ and $0.08 \mu \mathrm{g} / \mathrm{L} \mathrm{La}, 0.04 \mu \mathrm{g} / \mathrm{L}$ of $\mathrm{Ce}$, while the guano polluted filtered drop water in the left channel contained $22 \mu \mathrm{g} / \mathrm{L}$ of $\mathrm{Zn}, 0.46 \mu \mathrm{g} / \mathrm{L}$ of Cd, $3.5 \mu \mathrm{g} / \mathrm{L}$ of $\mathrm{Cu}$ and $0.157 \mu \mathrm{g} / \mathrm{L} \mathrm{La}, 0.29 \mu \mathrm{g} / \mathrm{L}$ of Ce, a 


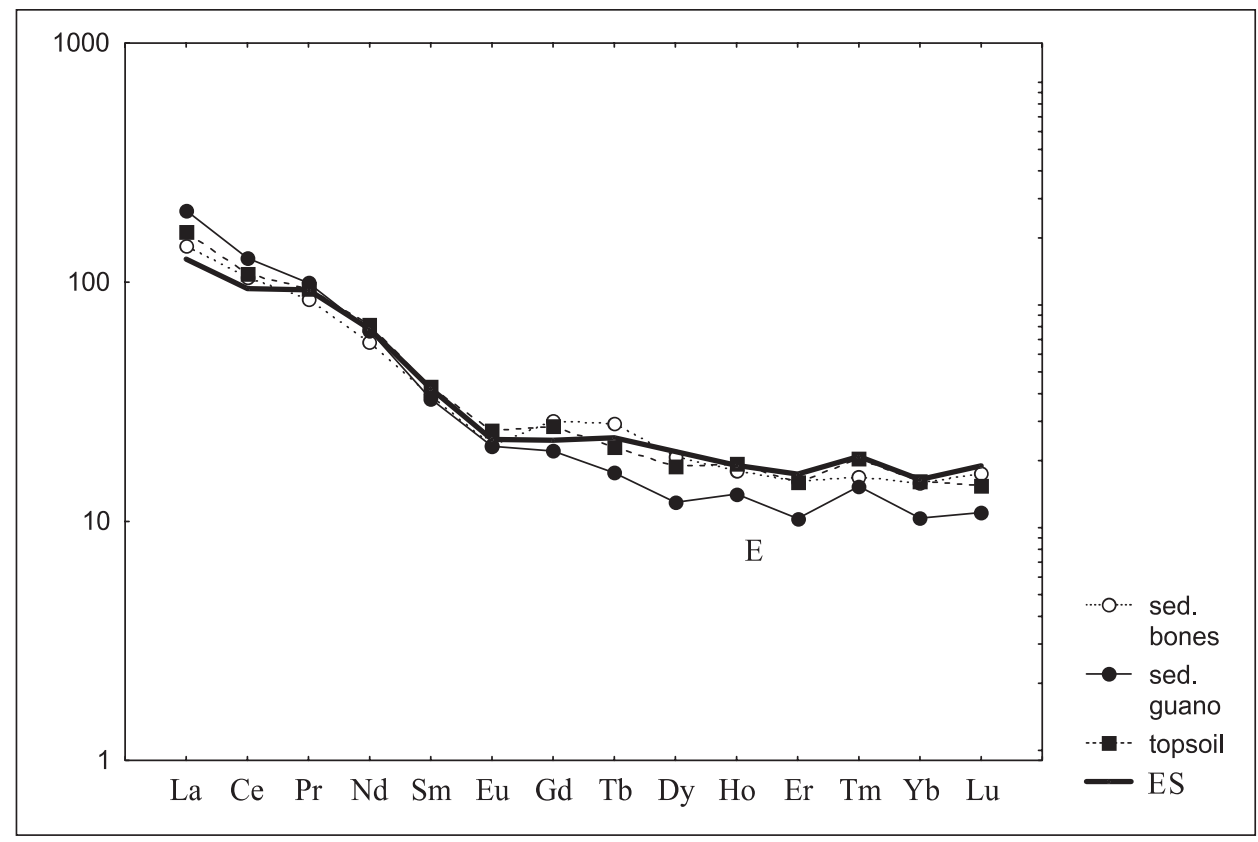

Fig. 5: Normalized REE patterns for cave sediments containing and those lacking guano, and topsoil, ES- European shale.

several fold increase (Table 5). The results of hydrochemical analysis where used for the calculation of $\mathrm{CO}_{2}$ partial pressure and the calcite, dolomite, aragonite saturation states of percolating waters with the aid of the geochemical speciation model NETPATH (Plummer et al., 1994). As a measure of mineral saturation the saturation index (SI) was used. It was determined that the percolating waters in the left channel were under-saturated with the respect to calcite, which is an indication of less favorable conditions for calcite precipitation. Also these waters were found to

Table 5: Chemical and isotopic contents of percolating waters (sample location/month/year).

\begin{tabular}{|c|c|c|c|c|c|c|c|c|c|c|c|c|c|c|c|c|}
\hline & $\begin{array}{c}\mathrm{Ca} \\
\mathrm{mg} / \mathrm{l}\end{array}$ & $\begin{array}{c}\text { Mg } \\
\text { mg/l }\end{array}$ & $\begin{array}{c}\mathrm{Na} \\
\mathrm{mg} / \mathrm{l}\end{array}$ & $\begin{array}{c}\mathrm{K} \\
\mathrm{mg} / \mathrm{l}\end{array}$ & $\begin{array}{r}\mathrm{HCO}_{3}^{-} \\
\mathrm{mg} / \mathrm{l}\end{array}$ & $\begin{array}{c}\mathbf{P}_{\text {tot }} \\
\mathrm{mg} / \mathrm{l}\end{array}$ & $\begin{array}{c}\text { Al } \\
\mu g / l\end{array}$ & $\begin{array}{c}\mathrm{Fe} \\
\mu \mathrm{g} / \mathrm{l}\end{array}$ & $\begin{array}{c}\mathrm{Cu} \\
\mu \mathrm{g} / \mathrm{l}\end{array}$ & $\begin{array}{c}\mathrm{Zn} \\
\mu \mathrm{g} / \mathrm{l}\end{array}$ & $\begin{array}{c}\mathrm{Cd} \\
\mu \mathrm{g} / \mathrm{l}\end{array}$ & $\begin{array}{c}\mathrm{Pb} \\
\mu \mathrm{g} / \mathrm{I}\end{array}$ & $\mathrm{pH}$ & $\begin{array}{c}\mathrm{T} \\
{ }^{0} \mathrm{C}\end{array}$ & $\begin{array}{c}\delta^{18} \mathrm{O} /{ }^{16} \mathrm{O} \\
(\%)\end{array}$ & $\begin{array}{c}\delta^{2} \mathbf{H} /{ }^{1} \mathbf{H} \\
(\%)\end{array}$ \\
\hline $\begin{array}{l}\text { Right } \\
\text { channel/5/99 }\end{array}$ & 71 & 0,76 & 1,57 & 0,03 & 200 & 0,2 & 6 & 324 & 0,4 & 0,8 & 0,01 & 0,2 & 7,48 & 14,1 & $-5,61$ & $-35,5$ \\
\hline $\begin{array}{l}\text { Right channel } \\
/ 7 / 99\end{array}$ & 74 & 0,835 & 1,6 & 0,038 & 210 & 0,04 & 11 & 338 & 0,6 & 1 & 0,01 & $-0,1$ & 7,58 & 14,5 & $-5,46$ & $-33,1$ \\
\hline $\begin{array}{l}\text { Right channel } \\
\text { /9/99 }\end{array}$ & 71 & 0,792 & 1,49 & 0,033 & 201 & 0,03 & 7 & 329 & 0,4 & 5,4 & 0,07 & 1,4 & 7,56 & 14,3 & $-5,52$ & $-33,6$ \\
\hline $\begin{array}{l}\text { Right channel } \\
\text { lake/5/99 }\end{array}$ & 51 & 0,681 & 1,26 & 0,033 & 140 & 0,1 & 10 & 240 & 0,4 & 2,7 & 0,02 & 0,5 & 7,89 & 16 & $-5,7$ & $-35,6$ \\
\hline $\begin{array}{l}\text { Left channel } \\
/ 5 / 99\end{array}$ & 67 & 0,728 & 1,59 & 0,043 & 191 & 0,48 & 103 & 372 & 3,5 & 22,5 & 0,46 & 0,8 & 7,5 & 14 & $-5,79$ & $-35,2$ \\
\hline $\begin{array}{l}\text { Left channel } \\
/ 7 / 99\end{array}$ & 59 & 0,749 & 1,8 & 0,038 & 169 & 0,22 & 14 & 277 & 0,4 & 1 & 0,01 & 0,1 & 7,54 & 14,3 & $-5,68$ & $-36,1$ \\
\hline $\begin{array}{l}\text { Left channel } \\
/ 9 / 99\end{array}$ & 71 & 0,791 & 1,56 & 0,027 & 202 & 0,22 & 5 & 328 & 0,3 & 0,6 & $-0,01$ & 0,3 & 7,52 & 14,2 & $-5,6$ & $-36,2$ \\
\hline
\end{tabular}




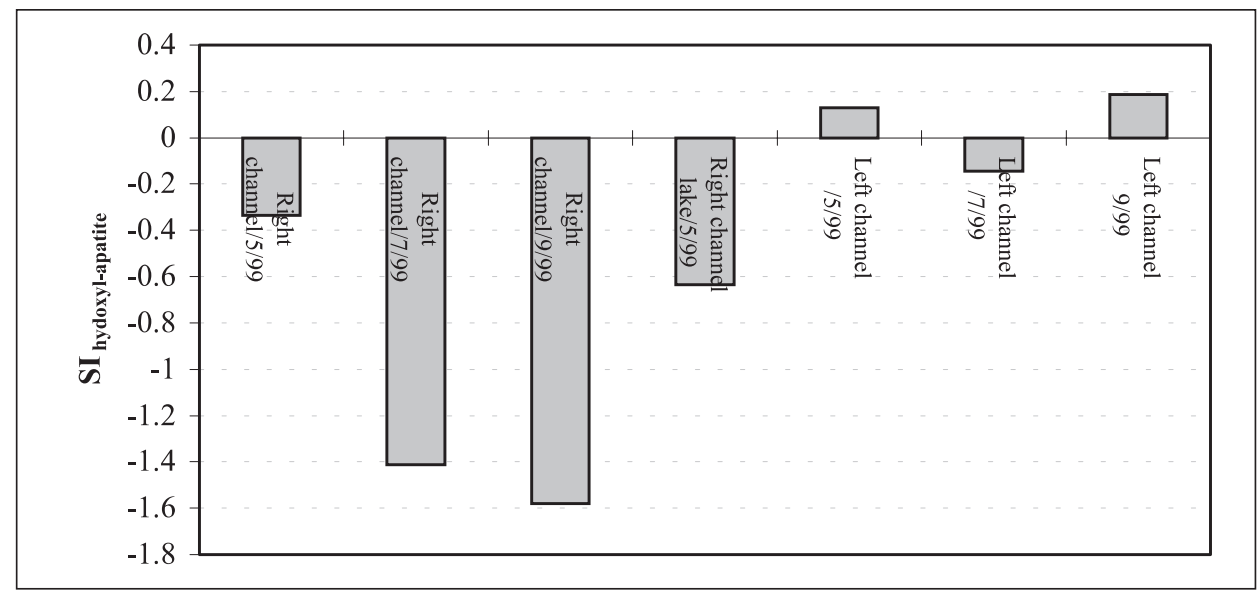

Fig. 6: The percolating water saturation in respect to hydroxyl-apatite (sample location/month/ year).

be saturated in respect to hydroxyl-apatite (Fig. 6). The trace elements found in elevated concentrations in percolating waters are the ones that were also found to be most mobile after $1 \mathrm{M} \mathrm{KCl}$ extractions from guano-polluted sediments. Therefore percolating waters are enriched in these elements when they pass over the guano. The isotopic composition of the studied percolating water samples ranges from -5.46 to $-5.79 \%$ ofor oxygen-18, and from -33.1 to $-36.2 \%$ for deuterium (Table 5.), which is typical for infiltrated precipitation waters of the region under a marine influence.

\section{CONCLUSIONS}

The primary goal of the study was to determine geochemical baseline values for the cave sediments and environment as well as possible influences from several decades of heavy traffic or war activities in the vicinity of Modrić. The results however indicate that the cave environment chemistry is under a considerable influence of bat guano as a natural contaminant. The natural accumulation of $\mathrm{Cu}, \mathrm{Zn}, \mathrm{Th}, \mathrm{U}, \mathrm{Sb}$ and $\mathrm{Cd}$ obviously exceeds possible anthropogenic contributions of the same metals. This is partly confirmed by low contents of $\mathrm{Pb}$ in the cave sediments in comparison with the topsoil above the cave although this should be confirmed yet with the aid of $\mathrm{Pb}$-isotope analysis. The presence of guano has led to the formation of various phosphate minerals as the reaction products of clay minerals and guano (taranakite, vivianite, crandallite) and bedrock (calcite and limestone) with guano (hydroxyl-apatite). During sampling of sediments it was observed that a dark film of guano is dispersed widely over both bedrock and sediments on the cave floor. These materials were also found to contain high concentrations of $\mathrm{Cu}, \mathrm{Zn}$ and $\mathrm{Cd}$. The very high concentration of $\mathrm{Zn}$ (Cu less) in almost pure crusts of hydoxyl-apatite that developed as a consequence of reaction phosphoric acid with flowstone on inclined surfaces indicate that detailed studies could lead to the identification of rare cave $\mathrm{Zn}$ phosphates making the cave 
quite unique in a mineralogical sense. The analysis of various extracts of sediments and percolating water shows that the acid guano environment has the effect on deterioration both of sediment clay minerals (high concentrations of exchangeable $\mathrm{Al}$ ), flowstone and bones fragments within the sediments. The performed studies should be considered as preliminary and further geochemical and mineralogical (as well as archeological) research and analysis of the cave environment should be undertaken before it is used for tourism.

\section{REFERENCES}

Ayati, M., Lundager Madsen, H. E., 2000: Crystallization of some heavy metal phosphates alone and in the presence of calcium ion. Journal of Crystal Growth 208, 579-591.

Cancain, G., Coltroti, M. \& Princivalle, F., 1989: Mineralogical study on hydroxyl-apatite encrustations in caves of the Gorizia Karst (Italy). Bollettino della Societa Adriatica di Scienze, LXXXI, 21-28.

Cancain, G., Miniussi, D. \& Princivalle, F., 1992: Crandallite, O.C.P. ed altri fosfati nell' Abisso Bonetti (Carso Goriziano). Studi e Ricerche, num. 1, pp. 31-43, Societa di Studi Carsici Linder, Gorizia.

Cancain, G. \& Princivalle, F., 1997: Mineralogia e stratigrafia del deposito di riempimento della "Grotta Due Piani" (Carso Goriziano). Studi Trentini di Scienze Naturali - acta geologica, v. 71 (1994), p0. 79-90, Trento.

Fischer, W.R., 1988: Microbiological reactions of iron in soils. In: Stucki, J.W., Goodman, B.A. \& Schwrtman, U. (eds.) Iron in soils and clay minerals. NATO Advanced Study Institutes Series. C 217, 715-748.

Hall, G.E.M., Vaive, J.M., Beer, R. \& Haoshi, M., 1996: Phase selective leaches for use in exploration geochemistry. In EXTECH I: A Multidisciplinary Approach to Massive Sulphide Research in the Rusty Lake-Snow Lake Greenstone Belts, Manitoba, (ed), G.F. BonhamCarter A.G.Galley and G.E.M. Hall; Geological Survey of Canada, Bulletin 426, 169-200.

Herak, M., 1986: A new concept of geotectonics of the Dinarides. - Acta geol., 16, 1, 1-42, Zagreb.

Hill, C.A., 1976: Cave Minerals. National Speleological Society, Huntsville, Alabama, Speleo Press, p 137.

Kuhta, M., Božičević, S., Kapelj, S. \& Miko, S., 1999: The protection and utilization study of the natural environment of the Modrić cave and its surroundings. Open file report, Institute of Geology, Zagreb, 68p.

Malez, M., 1987: Quaternary vertebrata fauna from Modrić cave near Rovanjska. Rad Yug. Ac. Sci \& Art 431, 141-154, Zagreb.

Murray, J. W. \& Deitrich, R. V., 1956: Brushite and Taranakite from Pig Hole Cave, Giles County, Virginia. American Mineralogist, 41, p. 616-626.

Miko, S., Peh, Z., Bukovec, D., Prohić, E. \& Kastmüller Ž., 2000: Geochemical baseline mapping and lead pollution assessment of soils on karst in Western Croatia. - Natura Croatica Vol. 9, No 1, p 41-59. 
Plummer, L.N., Prestemon, E.C. \& D.L. Parkhurst, 1994: An interactive code (NETPATH) for modeling net geochemical reactions along flow path, Version 2.0. USGS Water-Resources Investigation Report 94-4169, Reston, Virginia.

Suess, E., 1978: Mineral phases formed in anoxic sediments by microbial decomposition of organic matter. Geochimica et Cosmochimica Acta 43, 339-352.

Tessier, A., Campbell, P.G.C., \& Bisson, M., 1979: Sequential extraction procedure for the speciation of particulate trace metals. Analytical Chemistry 51, 844-851.

Vrbek, B., 1998: Prilog poznavanja sadržaja teških metala u sedimentima jamskog sustava Lukina jama -Trojama na Velebitu. Rad. Šumar. inst. 33(1): str. 95-106.

\section{OCENA OKOLJSKE GEOKEMIJE V JAMI MODRIĆA NA HRVAŠKEM, PREDEN BO ODPRTA ZA TURIZEM}

\section{Povzetek}

Vhod v jamo Modrića leži $30 \mathrm{~m}$ nad morjem, približno $125 \mathrm{~m}$ od obale in $70 \mathrm{~m}$ od glavne obalne ceste Rijeka-Zadar na Hrvaškem. Jama je razvita v krednih apnencih z rahlo nagnjenimi, a $\mathrm{v}$ glavnem vodoravnimi dvoranami in rovi v skupni dolžini $829 \mathrm{~m}$. Zaradi primerne oblike in številnih kapnikov, kakor tudi paleontoloških in arheoloških ostankov, ohranjenih v jamskih sedimentih, je jama mikavna za turiste. Zaradi tega je bila izdelana predhodna podrobna študija, ki vsebuje meritve jame, analize vode in jamskih sedimentov ter tudi ocene starosti, še preden bi jamo uredili za turistični obisk. Meljasta ilovica z guanom vsebuje mnogo kremena, ilita in taranakita ter manjše količine vivianita in visoke koncentracije bakra $(2869 \mathrm{mg} / \mathrm{kg})$, cinka $(951 \mathrm{mg} / \mathrm{kg})$ in kadmija $(28 \mathrm{mg} / \mathrm{kg})$. Sedimenti, pomešani z guanom, so obogateni z rahlim REE in s povišanimi koncentracijami $\mathrm{U}$, Th in $\mathrm{Hg}$ v primerjavi s prstjo na površju. Sedimenti z delci kosti vsebujejo kremen, ilit, kalcit in hidroxylapatit, a manj carnalita in nizke vrednosti težkih mineralov. Vsi analizirani sedimenti kažejo različno stopnjo kontaminacije $\mathrm{Cu}$ in $\mathrm{Zn}$ zaradi razsutega guana. S sekvenčno ekstrakcijo je bilo mogoče določiti metalogene faze $\mathrm{v}$ jamskih sedimentih, ter razločiti možne litološke in okoljske vplive. Večina $\mathrm{Zn}$ in $\mathrm{Cu} v$ jamskih sedimentih kot tudi hidroxylapatitna skorja so v zvezi z železovim in manganovim hidroksidom ter organskimi delci. Organski delci v vzorcih sedimentov so pomembni, ker kažejo neposredni vpliv guana in hidroxylapatitnih skorij, medtem ko je v vzorcih sedimentov z drobci kosti najpomembnejši hidroksid. Residualni del vsebuje več kot $45 \%$ celotnega $\mathrm{Zn}$ v hidroxylapatitnih skorjah, kar kaže na vključitev Zn v kristalno strukturo. Sedimenti z guanom vsebujejo v najbolj mobilnih adsorbcijskih frakcijah in v karbonatih 5 do $10 \% \mathrm{Zn}$ in $\mathrm{Cu}$. Rezultati hidrokemijskih analiz jamske vode kažejo takšno stopnjo nasičenosti prenikajočih voda s kalcitom, da se siga še vedno, a zelo počasi, odlaga. Glede na nenasičeno okolje v levem rovu, se tam odlaga manj kalcita. V dveh primerih smo opazovali vpliv guana na prenikajočo vodo v levem rovu, kjer je večja koncentracija ortofosfatov glede na hidroxylapatit. Te vode imajo tudi višjo vsebnost $\mathrm{Cu}, \mathrm{Al}, \mathrm{Mn}$, $\mathrm{Cd}, \mathrm{Zn}, \mathrm{K}$, nitratov in amonijaka. Po vsebnosti $\delta^{18} \mathrm{O}$ in $\delta^{2} \mathrm{H}$ je prenikajoča voda podobna padavinam na tem obalnem področju. Rezultati geokemijskega preučevanja jamskih sedimentov v jami Modrića kažejo močan vpliv guana na kemizem jamskega okolja. 